\title{
SOCIAL CAPITAL AND THE MARTIAL LAW TECHNOCRACY: THE MAKING AND UNMAKING OF A POWER ELITE
}

\author{
Teresa S. Encarnacion Tadem, PhD \\ University of the Philippines \\ Diliman, Quezon City
}

\begin{abstract}
This paper attempts to show the extent to which a faction of the Philippine technocracy during the martial law years utilized its social capital (used interchangeably with cultural capital) to become a potent economic bloc in society only to see it gradually depleted.Led by then Prime Minister and concurrent Finance Minister Cesar E.A. Virata, this bloc consisted of key senior economic officials who were closely associated with IMF-World Bank policies. Their social capital was founded on their family and educational backgrounds, paving the way for their acquisition of the technical expertise required by the business community and later, by government. What set them apart from the other pre-martial law technocrats was their support for an export-oriented and foreign investment-friendly industrialization policy shared by Marcos and the IMF-World Bank. The social capital of this bloc grew due to their ability to access foreign loans, gain international support, and function as a deterrent to corruption.Marcos, however, proceeded to undermine this bloc's capital by doing the following: 1) limiting the Virata faction to the economic sphere and making sure it was not "politically-threatening"; 2) "factionalizing" the technocracy resulting in non-Virata technocrats pursuing their own projects; and 3) and nurturing crony capitalism and corruption through Mrs. Marcos and his "chief cronies" to the detriment of the Virata faction's economic policies.But despite the opportunity provided by the political and economic crisis of the early 1980 os and initial IMF-WB support,the Virata-led bloc's social capital rapidly deteriorated because of its inability to now access the needed loans and the withdrawal of US support for the Marcos dictatorship. This further highlighted the unsustainable and relative vulnerability of its social capital.
\end{abstract}

\section{About the Author}

Teresa S. Encarnacion Tadem, PhD is Professor at the Department of Political Science at the University of the Philippines, Diliman and President of the Philippine Political Science Association. She previously served as its Department Chair as well as Director of the UP Third World Studies Center and editor of its journal Kasarinlan. Her latest publications include the edited volume, Localizing and Transnationalizing Contentious Politics: Global Civil Society Movements in the Philippines (Lexington Press 2009) and co-edited volume, Marxism in the Philippines: Continuing Engagements (Anvil 2010). She has 
published articles in local and international journals as well as book chapters on Philippine technocracy and U.S.-led capitalism, Philippine technocracy as a bulwark of corruption, popularizing technocratic decision-making and the WTO negotiations, the middle class and political reform: examining Philippine technocracy and the trials and tribulations of Virata as "chief technocrat". A forthcoming book is the co-edited volume, The Politics of Technocracy in Southeast Asia (ISEAS, Singapore). 


\section{Introduction}

MOST OF THE LITERATURE ON TECHNOCRACY focuses on its recruitment into government because of their expertise. It was this technical expertise which paved their way into the "power elite" of society. In the Philippine experience, however, it is also significant to know how they acquired this. The manner in which their abilities were developed defines not only how they were recruited into government but also the nature of their political and economic leverage in the decision-making process. This is especially so in the case of Philippine technocracy which was perceived to be a faction of the "power elite" during the martial law period (19721986), together with the other two: the military and the leadership's relatives and cronies. Furthermore, although some of these technocrats possessed political and/ or economic traits that generally characterized the Philippine "power elite"-that is, coming from a landed family and occupying a political place in governmenttheir government appointment was generally deemed based on merit as experts in their fields and they were perceived to be "apolitical." Moreover, there were also technocrats who came from the middle and lower classes of society. In the process, the paper hopes to fill up a gap in understanding the role of Philippine technocracy as a "power elite" not in the usual framework of contemporary development theories which Peter Evans $(1997,1)$ has argued has generally focused its attention on macro results. But also considering "micro-institutional foundations on which they depend." These generally refer to informal norms and networks which form the basis of social and cultural capital.

The paper draws its idea from Amir's (2007) use of Pierre Bourdieu's cultural concept in examining the reign of B.J. Habibie in New Order Indonesia which looked into the family and educational background of Habibie which brought him into the apex of power during the Suharto regime. Thus, cultural capital refer to traits which emanate from a person which facilitates his/her entry into crucial networks in society. Cultural capital is closely linked with social capital which is interchangeably linked as used by Bourdieu. As Bourdieu pointed out, social capital refers to "the advantages and opportunities accruing to people through membership in certain communities." This is further expounded by Coleman who uses the term "to describe a resource of individuals that emerges from their social ties" and is based primarily in interpersonal relations (Woolcock 1998). Because of their closeness in meaning in the manner which these are utilized, this paper will use cultural and social capital interchangeably.

"This article is based on the research project of the author: "Social Origins of the Martial Law Technocrats: Paving the Path for Government Service." This research project is funded by the Office of the Vice President for Academic Affairs through the University of the Philippines Research Grant, Creative and Research Scholarship Fund, 1 February 2012 to 31 January 2013.

Kritika Kultura 20 (2013): -094

(c) Ateneo de Manila University

<http://kritikakultura.ateneo.net> 
This paper, therefore, examines the nature of the Filipino technocrats' social capital which paved the way for their recruitment into the Marcos administration to become key economic players during that period. It will highlight how the nature of technocracy's cultural/social may help explain the character of its influence which paved the way to their key role in the martial law administration as a "power elite". It will, however, also show that the nature of their cultural/social capital was not enough to sustain their role as a power elite during the martial law period as it was gradually eroded by no less than the leadership.

The first part of the paper will, therefore, look into the family and educational backgrounds of the technocrats which laid the basis for their cultural capital which paved their way into the influential Philippine business community. This further grew in the form of social capital, i.e., capital which grows from establishing relationships in communities as will be seen in the second part. The third part, on the other hand, will show how technocracy's cultural/social capital was further enhanced by their recruitment into government as particularly facilitated by their shared economic vision with the leadership and the country's major lending institutions, i.e., the International Monetary Fund (IMF) and the World Bank, as will be discussed in the fourth part. The fifth part, on the other hand, will highlight the limitations of technocracy's cultural/social capital during the latter part of the martial law as seen in the manner in which the leadership debased this. While the last part will focus on how the political and economic crisis has led to the expansion as well as the contraction of technocracy's cultural/social capital.

This paper will focus mainly on the experiences of six technocrats who were the key senior economic officials of President Ferdinand E. Marcos and who formed one major influential technocracy faction during the martial law regime which was referred to as the IMF/World Bank faction. This bloc was perceived to have the closest link with the country's two major lending institutions. The primus interpares of this faction was Cesar E.A. Virata, former prime minister and minister of finance and the other technocrats identified with this faction were Vicente T. Paterno, former head of the Board of Investments and trade minister;Placido Mapa Jr., former Philippine alternative executive director to the World Bank; and Armand V. Fabella, former head of the Philippine Reorganization Commission, who are from the country's landed elites and Jaime C. Laya, former budget minister and Central Bank governor who come from the middle class; and Manuel S. Alba, former budget minister who traces his origins from the lower class in Philippine society. This paper benefits substantially from interviews conducted with key technocrats during the martial law period, under the three-year (20072010) Japan Society for the Promotion of Science-sponsored research project, 
"Economic Policy-making and the Philippine Development Experience, 1970-1985: An Oral History Project," of which the author was a team member. ${ }^{1}$

\section{Family and Educational Backgrounds}

The family backgrounds of the technocrats highlight two important factors that facilitated their recruitment into government service. First, it paved the way for their education that gave them the technical expertise needed by the government. As Pierre Bourdieu pointed out, cultural capital relating to family origins has a strong correlation with academic success later in life (Swartz 2007, 75-76). Second, their networks or cultural capital enabled them to forge ties with people who recruited them into government. Together with the academic community, these were the closely intertwined communities where one witnessed the growth of technocracy's cultural capital combining their scientific and professional credentials (Amir 2007, 85). In pure technocracy, technical knowledge would serve as the base of power, with education and training providing credentials for access to it. Those who rule would justify themselves by appealing only to technical expertise grounded in scientific forms of knowledge (Fischer 1990, 18). Such a technical expertise is generally acquired from education, and this is where the family backgrounds of the Philippine technocrats enabled them to acquire not only basic but, more important, higher education to obtain expertise in their fields. The technocrats, in general, refer to the scientists, including physicists, mathematicians, chemists, biologists, engineers, computer programmers, and others who work in varying degrees of applied or pure research. For the Philippine technocrats, they had their undergraduate/graduate degrees in engineering, economics, and business administration and finance.

The key technocrats in the Marcos administration came from different classes in society. Placido Mapa Jr. seems to typify the technocrats who came from the upper class of Philippine society. He is a member of the Ledesma-Lizares-Alunan landed clan of Negros Occidental. In the 1950s, his mother's family was considered part of the national landowning economic elite; the family controlled major nonmanufacturing firms in the list of the top 100 corporations in the 1970 (Rivera 1994, 95). The Mapas were also members of the political elite. His grandfather served in the country's National Assembly while his father was President Elpidio Quirino's commerce and industry secretary. Vicente Paterno, on the other hand, typifies another type of landed elite whose wealth was augmented when his father, who was a medical doctor, joined the family business of his brother-inlaw Vicente Madrigal whose family is part of the "prominent colonial landed elites who successfully diversified into manufacturing ..." (Rivera 1994, 25). Like Paterno,

1 The project team also tried to interview Marcos's Economic Planning Minister Gerardo Sicat who was a key player in this technocracy faction as he was Marcos' Director-General of the National Economic and Development Authority, but he was unavailable.

Kritika Kultura 20 (2013): -094

(C) Ateneo de Manila University

<http://kritikakultura.ateneo.net> 
Armand Fabella also hailed from a wealthy landed family from Pagsanjan, Laguna. His father was the first Filipino certified public accountant in the US and made good fortune from the US stock market. ${ }^{2}$

It is Cesar E. A. Virata who seems to typify the Filipino technocrat who came from a middle-class background. Although his family owned land, he said that this was not much. For Virata, what pulled the family through was his father's profession, that is, a math professor at the University of the Philippines (UP), ${ }^{3}$ the national elite school. Like Virata, Jaime Laya's father, Juan Cabreros Laya, was also a UP professor and renowned writer whose books included the popular textbook Diwang Kayumanggi. ${ }^{4}$ As for Manuel Alba Jr., his background shows how someone from the lower class could become a technocrat as he described himself as "very poor." He came from a family of eleven children, and his father was a municipal treasurer, in the lower rank of the government bureaucracy. ${ }^{5}$

Educational mobility. Their education has generally classified technocracy as belonging to the middle class not because of "their class origins but as a result of having particular credentials and know-based expertise ... The 'mental' work engaged in by the middle class usually requires a college education and often leads to the planning, supervision or direction of other people's work" (Croteau 1995, xii). Mapa is a product of the elite educational system in the Philippinesthat is, he went to the exclusive boy school of De La Salle for his elementary and secondary schooling; for college, he went to Ateneo de Manila. He proceeded to earn a master's degree in economics in St. Louis University and later on proceeded to Harvard University to obtain a doctor's degree in economics. ${ }^{6}$ Vicente Paterno had a similar educational background as Mapa: he also went to De La Salle for his secondary schooling. But for elementary, Paterno was a product of the Philippine public school system. Paterno pursued his university education in Ateneo de Manila, but when the school closed down because of the war in 1941, he continued at the University of the Philippines where he graduated in 1948 with a bachelor of science degree in mechanical engineering. ${ }^{7}$ Armand Fabella, on the other hand,

2 Fabella, Armand V. 2008. Interview by Yutaka Katayama, Cayetano Paderanga, Temario Rivera and Teresa S. Encarnacion Tadem. Tape recording. August 11. Fabella Residence, Harvard St., Wack Wack Subdivision, Mandaluyong City, Philippines.

3 Virata, Cesar E.A. 2007. Interview by Yutaka Katayama, Cayetano Paderanga and Teresa S. Encarnacion Tadem. Tape recording. November 21. RCBC Plaza, Makati City, Philippines.

4. Virata, Cesar E.A. 2007. Interview by Yutaka Katayama, Cayetano Paderanga and Teresa S. Encarnacion Tadem. Tape recording. November 21. RCBC Plaza, Makati City, Philippines.

5 Alba, Manuel S. 2008. Interview by Yutaka Katayama and Teresa S. Encarnacion Tadem. Tape recording. December 12. Third World Studies Center, Palma Hall, University of the Philippines, Diliman, Quezon City, Philippines.

6 Mapa, Placido. 2009. Interview by Yutaka Katayama and Teresa S. Encarnacion Tadem. Tape recording. March 13, Metrobank Plaza, Gil Puyat Avenue, Makati City.

7 Paterno, Vicente T. 2008. Interview by Yutaka Katayama, Temario Rivera and Teresa S. Encarnacion Tadem. Tape recording. August 15. 11th Floor Columbia Tower Ortigas Ave., Mandaluyong City, Philippines.

Kritika Kultura 20 (2013): -094

(C) Ateneo de Manila University

<http://kritikakultura.ateneo.net> 
attended high school in the United States and obtained an undergraduate degree in economics from Harvard University. ${ }^{8}$

As for Virata, he seems to typify the educational path of the middle class in Philippine society who was a product of the country's public school system. He studied at the elementary and secondary schools of the University of the Philippines, with a year in high school at the Imus Institute. Alba, on the other hand, finished elementary in West Visayas State University in 1949, graduating valedictorian. He also graduated valedictorian from Iloilo National High School in 1953. As for Laya, he attended Alejandro Albert Elementary School in Dapitan and proceeded to Arellano High School in Manila.The educational background of these technocrats was crucial to their admission to the elite University of the Philippines.

Like his grandparents and parents, Laya went to the University of the Philippines where he finished with a Bachelor of Science in Business Administration (accounting; magna cum laude) in $1957 .{ }^{9}$ As for Virata, he obtained a BS Mechanical Engineering degree in 1952. In that year, he also graduated with a BS Business Administration degree, cum laude, from UP. Upon graduation, hejoined the UP College of Business Administration (CBA) as an instructor in 1952 and later on went on to become its Dean. ${ }^{10}$ Like Virata, Laya also went on to become faculty as well as dean at the UP CBA. Virata's and Laya's family background depicts a middle class background but not the middle class from the bourgeoisie, which, as Anthony Giddens pointed out, is based on market capacity - that is, ownership of property. The Virata family was middle class owing to their possession of qualifications (Robison and Goodman 1996, 12).

Alba seems to typify what Bourdieu observes as children coming from the lower class who are able to overcome the lack of cultural capital resource by adopting a flexible and open orientation toward the demands of an inherently middle-class educational system for which they are previously unprepared (Wacquant 2005, 9). Alba's public elementary and secondary schooling enabled him to study in UP where he obtained in 1957 a Bachelor of Science in Business Administration (accounting) degree from the University of the Philippines. After graduation he worked as assistant instructor at the UP CBA. ${ }^{11}$

US education as a potent cultural capital. Philippine technocracy was generally the product of US education. For those who could afford it like Mapa, Fabella, and Paterno, the choice was Harvard University. Unlike the UP-based technocrats, the more well-off technocrats were able to pursue graduate degrees

8 Fabella, Armand V. 2008. Interview by Yutaka Katayama, Cayetano Paderanga, Temario Rivera and Teresa S. Encarnacion Tadem. Tape recording. August 11. Fabella Residence, Harvard St., Wack Wack Subdivision, Mandaluyong City, Philippines.

9 Laya, Jaime. 2009. Interview by Yutaka Katayama, Cayetano Paderanga and Teresa S. Encarnacion Tadem. February 9. Tape recording. 1000 United Nations Avenue corner San Marcelino St., Ermita, Manila 1007, Philippines. 10 Virata, Cesar E.A. 2007. Interview by Yutaka Katayama, Cayetano Paderanga and Teresa S. Encarnacion Tadem. Tape recording. November 21. RCBC Plaza, Makati City, Philippines.

11 Manuel S. Alba, biodata

Kritika Kultura 20 (2013): -094

(C) Ateneo de Manila University

<http://kritikakultura.ateneo.net> 
on their own. Paterno did this with financial assistance from his parents and his own personal savings working as a sugar mill engineer. He pursued a Master of Business Administration (MBA) at Harvard University in $1953 .{ }^{12}$ For Virata, Alba, and Laya, as UP faculty, they enjoyed the opportunity to study in the United States through US fellowships c/o UP. ${ }^{13}$ The US fellowships generally came from the Mutual Security Agency (MSA) fellowship, a precursor of the US Agency for International Development. ${ }^{14}$ In the case of Virata, he was given a fellowship to study at Wharton School, University of Pennsylvania where he obtained an MBA major in industrial management in 1953. As for Alba, he pursued a master of business administration (marketing and transportation) at the University of Minnesota in 1961. In 1967, he obtained his $\mathrm{PhD}$ in management science and business administration in Northwestern University, Chicago and Evanston, Illinois, USA. ${ }^{15}$ And for Laya, he pursued a master's degree in industrial management from Georgia Institute of Technology in 1961 and doctor's degree in financial management from Stanford University in 1966. Being US educated facilitated the technocrats', who were coming from the middle- and lower classes, entry into the elite-controlled business community. As pointed out by Bourdieu, this "shows how the school legitimates the dominant social order by naturalizing social differences through the ideology of 'natural gifts' or through the allocation of scholastic qualifications" (Poupeau 2000, 71).

\section{Expanding Social Capital through the Philippine Business Community}

The importance of technocracy to the business community as facilitated by their educational backgrounds enhanced further its social capital. As noted,

while financial, environmental, physical and human capital are vital to their community, the most critical capital of all is social capital. Social capital is the only one that you build by using. It refers to the ability of community members to work together. Without this, none of the other forms of capital can be developed to improve quality of life. Social capital enhances the benefits of investment in physical and human capital (Putnam 1993 and Civic Practices Network 1996).

This was seen in the technocrats upon returning to the Philippines with graduate degrees in the early 1950s. The "first set" of martial law technocratsFabella, Mapa, Virata, and Paterno-encountered "the emergence of a vibrant

12 Paterno, Vicente T. 2008. Interview by Yutaka Katayama, Temario Rivera and Teresa S. Encarnacion Tadem. Tape recording. August 15. 11th Floor Columbia Tower Ortigas Ave., Mandaluyong City, Philippines.

13 Laya, Jaime. 2009. Interview by Yutaka Katayama, Cayetano Paderanga and Teresa S. Encarnacion Tadem. February 9. Tape recording. 10oo United Nations Avenue corner San Marcelino St., Ermita, Manila 1007, Philippines. 14. Virata, Cesar E.A. 2007. Interview by Yutaka Katayama, Cayetano Paderanga and Teresa S. Encarnacion Tadem. Tape recording. November 21. RCBC Plaza, Makati City, Philippines.

15 Manuel S. Alba, biodata

Kritika Kultura 20 (2013): -094

(C) Ateneo de Manila University

<http://kritikakultura.ateneo.net> 
manufacturing sector" and of Filipino entrepreneurs who were perceived to provide the foundation of Filipino industrial bourgeoisie, "projecting alternative strategies for development" (Rivera 1994.3). Beginning in the 1950 os and 1960s, too, "the closely held conglomerates of the major oligarchic families also became highly diversified units." These families combined manufacturing, finance, agriculture, commerce, services, urban real estate, and other business interests, all under one roof (Hutchcroft 1998, 38). Among the families who took advantage of technocratic skills were the Lopezes of the sugarcane plantation-owning family from Negros Occidental who hired Virata for their newspaper, The Manila Chronicle. They generally wanted Virata to bring in his expertise on "time and motion" which he acquired in his graduate studies, to cut costs and bring more profits to the company. ${ }^{16}$ Paterno, like Virata, also worked for a company owned by the Lopezes in 1964, i.e., Meralco, the country's leading electric company. Lopez's son, Eugenio Lopez Jr., was Paterno's classmate in Harvard Business School. ${ }^{17}$ During the 1950s, the banking system was also actively recruiting graduates from the United States as this period also signaled "the rapid growth and development of a complex and comprehensive financial system" (Castro 1974, 23 \& 26). Mapa took advantage of this situation, and his first job was with the First National Citibank (now Citibank). ${ }^{18}$ Mapa also signified the technocrats coming from the upper landed classes whose families were diversifying into other businesses such as financing.

Technocrats and multinational corporations. The establishment or expansion of business ventures by the local elites included joint ventures with multinational corporations needing technocratic skills. Through the 196os, for example, the "major elite segments and dominant families of the local manufacturing class were closely linked with foreign capital ..." (Rivera 1994, 93). A firm that linked the technocrats with multinational corporations was the accounting firm SyCip Gorres Velayo \& Co. or SGV. Through SGV, Virata became a consultant for big multinational corporations like United Fruit Company and Castle \& Cooke, which were exploring the agribusiness potential in the Philippines. ${ }^{19}$ Alba, who worked with SGV as a bookkeeper, on the other hand, did a physical inventory of re-dried tobacco in Cooperative Exchange, a company owned by Harry Stonehill in La Union. ${ }^{20}$ As for Paterno, although he did not work for a US multinational corporation, he was employed by a development agency that was a joint venture

16 Virata, Cesar E.A. 2008. Interview by Cayetano Paderanga and Teresa S. Encarnacion Tadem. Tape recording. 3o September. RCBC Plaza, Makati City, Philippines.

17 Paterno, Vicente T. 2008. Interview by Yutaka Katayama, Temario Rivera and Teresa S. Encarnacion Tadem. Tape recording. August 15. 11th Floor Columbia Tower Ortigas Ave., Mandaluyong City, Philippines.

18 Mapa, Placido. 2009. Interview by Yutaka Katayama and Teresa S. Encarnacion Tadem. Tape recording. March 13, Metrobank Plaza, Gil Puyat Avenue, Makati City.

19 Virata, Cesar E.A. 2007. Interview by Yutaka Katayama, Cayetano Paderanga and Teresa S. Encarnacion Tadem. Tape recording. 19 December. RCBC Plaza, Makati City, Philippines.

2o Alba, Manuel S. 2008. Interview by Yutaka Katayama and Teresa S. Encarnacion Tadem. Tape recording. December 12. Third World Studies Center, Palma Hall, University of the Philippines, Diliman, Quezon City, Philippines.

Kritika Kultura 20 (2013): -094

(C) Ateneo de Manila University

<http://kritikakultura.ateneo.net> 
of the US Agency for International Development (USAID) and the government's National Economic Council (NEC). ${ }^{21}$

The link of the academic and business communities. Virata, Laya and Alba were all working as consultants for SGV while also holding a full-time job as UP CBA faculty. This signifies the importance of the technocrats to the business community whereby the similar nature of cultural capital and economic capital where both are very competitive and "whose scarcity and value could mean that cultural capital could be converted into a high commodity resource" (Fowler 2000, 2). The link between the academe and the business community also shows the coming together of two important capital: cultural (as expressed in the academe) and economic (as expressed in capital) (Wacquant 2005, 135). Furthermore, as Bourdieu and Coleman pointed out, cultural capital which is also expressed as social capital, gives "advantages and opportunities to people through membership in certain communities" (Woolcock 1998, 154). In the case of these technocrats, one saw this in their role in the academic and business communities.

\section{Recruitment into Government and the Growth of Technocracy's Social Capital}

In all these communities, the technocrats' were able to develop a key ingredient of social capital which refers to "features of social organization such as networks, norms, and social trust that enable people and communities to work together" (Putnam 1993 and CPN 1996). This paved the way for their inclusion into a third potent community in Philippine society, i.e., the government. The entry of the technocrats in the 1950 s and the 1960 os into government came at a time when there was a dramatic increase of power of the central government due to its implementation of import and exchange controls. This enabled the government to "control the direction of the economy and to make or break individual entrepreneurs" (Hawes 1987, 34-35).Furthermore, the Philippine state played an "increasingly important role in the economy through both its financial institutions and commercial regulations." This role started when it was the "distributor of US rehabilitation and reparation funds after World War II," and "by the late 1950s, its role was so pronounced" (McCoy 1994, 13). Given this context, what made the technocrats more attractive to government was the potency of the marriage of cultural and economic capital as exemplified by Mapa. Coming from a wealthy landowning family, Mapa acquired the technical expertise that allowed him to negotiate further the higher echelons not only of the business community but also of government not solely on familial or patrimonial ties but on merit as well. Like his grandfather and father, Mapa wanted a job in government and thus from

21 Virata, Cesar E.A. 2007. Interview by Yutaka Katayama, Cayetano Paderanga and Teresa S. Encarnacion Tadem. Tape recording. November 21. RCBC Plaza, Makati City, Philippines.

Kritika Kultura 20 (2013): -094

(C) Ateneo de Manila University

<http://kritikakultura.ateneo.net> 
Citibank he joined the government economic agency Program Implementation Agency (PIA) under Armand Fabella who was the director-general. His recruitment into the Macapagal administration was facilitated by his family network care of Rufino "Feny" Hechanova who was his cousin and who was President Diosdado Macapagal's Secretary of Trade and Industry. ${ }^{22}$ Mapa also personally knew Marcos's 1965 presidential campaign manager and later on executive secretary Rafael "Paeng" Salas as both their fathers were members of the Liberal Party. Mapa's father also had ties with politicians in the Nacionalista Party who were part of Marcos's group. ${ }^{23}$ Mapa's family background seems to depict the nature of elite families during that period who devote enormous resources "to the task of gaining and maintaining access to the political machinery ..." (Hutchcroft 1998, 41). Mapa's entry into government also typifies the role of members of the landowning elites who have expanded into business and who also entered government. This was particularly true of those coming from the country's landowning sugar elites. An example was the National Economic Council (NEC) chair Alfredo Montelibano Sr. who was "a sugar baron and industrialist as well as a politician" (Raquiza 2012, 74).

What marked a major difference between the previous land-owning technocrats and the middle-class martial law technocrats like Virata, Alba, and Laya, was that they were pulled to government service mainly because of their technical expertise and they generally came from the academe. But like the technocrats also coming from the upper class, what also brought them in were their networks. If the landed technocrats had their family, economic and political networks, the middle class martial law technocrats had their academic network, i.e., UP. As Coleman pointed out, social capital is used "to describe a resource of individuals that emerges from their social ties and is based primarily in interpersonal relations" (Woolcock 1998, 156; Portes and Landolt 1996, 2). This can be seen in the other technocrat's experiences. Virata's entry into government was because of Salas who was the UP vice president under UP President Carlos P. Romulo. Virata said that he knew Salas because they both belonged to UP's Pan Xenia Fraternity. When Marcos won the presidency in 1965, Salas asked Virata to join the Transition Committee on Finance and the Committee on Agriculture. His full-time offer to join government came in February 1967 where Virata was assigned to the Presidential Economic Staff (PES). ${ }^{24}$

As for Alba, it was UP professor Corpuz, a $\mathrm{PhD}$ of political science graduate from Harvard University, who brought him into government service. Corpuz was also considered a "technocrat" whose skills and training is in political science and not economics. Alba met Corpuz when the latter taught in UP Iloilo when Alba was still in secondary school. Corpuz went on to head the Development Academy

\footnotetext{
22 Mapa, Placido. 2009. Interview by Yutaka Katayama, Cayetano Paderanga, Temario Rivera and Teresa S. Encarnacion Tadem. Tape recording. March 27, Metrobank Plaza, Gil Puyat Avenue, Makati City.

23 Mapa, Placido. 2009. Interview by Yutaka Katayama and Teresa S. Encarnacion Tadem. Tape recording. March 13. Metrobank Plaza, Gil Puyat Avenue, Makati City.

24. Virata, Cesar E.A. 2007. Interview by Yutaka Katayama and Teresa S. Encarnacion Tadem. Tape recording. November 23. RCBC Plaza, Makati City, Philippines.
} 
of the Philippines (DAP), which served as a training ground for career bureaucrats and where Alba served as a founding director from 1971 to $1973 .{ }^{25}$ As for Paterno, he joined the government when Virata and Mapa offered him to head the Board of Investments (BOI), which was just a year old. ${ }^{26}$ Virata and Paterno were both undergraduate contemporaries in the UP College of Engineering and they were together in UP when Paterno was a lecturer at the UP CBA before entering government service. As to Laya, he was recruited into government service during the martial law period when National Economic and Development Authority (NEDA) Director-General Gerardo Sicat Jr. invited him to join the agency in 1974 as his deputy. ${ }^{27}$ Sicat, on the other hand, was invited by Virata to join him in the PES. Sicat at that time was a faculty of the UP School of Economics. He and Virata are fraternity brothers in UP's Pan Xenia.

\section{Shared Economic Vision with the Leadership}

As important, however, as the family, academic and business links which facilitated the martial law technocrats' entry into government was their shared economic vision with the leadership. That is, the relevance of the technocrats to Marcos can be seen in the context of how technocracy is viewed to support a political project that advocates experts as the dominant basis for organizing political power (Fischer 1990, 18). The technocrats whom Marcos favored shared with him the vision of an economy open to foreign investments. Mapa, for example, believes that aside from his political connections, another reason why Marcos retained him in government was that the president preferred the five-year development plan of the PES team headed by Armand Fabella, of which Mapa was part, to that of the NEC development plan. Mapa felt that Marcos did not like the NEC plan because it was too protectionist and nationalistic whereas the PES plan emphasized the need for foreign investments. ${ }^{28}$ Such a view was also generally shared by the other martial law technocrats. The clash between the PIA (which later on became the PES) and the NEC, which was headed by Filemon Rodriguez and later on by Hilarion Henares, was well known. Henares is a Doctor of Economics and is a graduate of Ateneo de Manila, University of the Philippines and the Massachusetts Institute of Technology. ${ }^{29}$ When martial law was declared, Marcos retained the technocrats in the PES. These technocrats were already at that time working closely with the International Monetary Fund (IMF). ${ }^{30}$

25 Manuel S. Alba, Biodata.

26 Paterno, Vicente T. 2008. Interview by Yutaka Katayama, Temario Rivera and Teresa S. Encarnacion Tadem. Tape recording. August 15. 11th Floor Columbia Tower Ortigas Ave., Mandaluyong City, Philippines. 27 Laya, Jaime. 2009. Interview by Yutaka Katayama, Cayetano Paderanga and Teresa S. Encarnacion Tadem. February 9. Tape recording. 1000 United Nations Avenue corner San Marcelino St., Ermita, Manila 1007, Philippines. 28 Laya, Jaime. 2009. Interview by Yutaka Katayama, Cayetano Paderanga and Teresa S. Encarnacion Tadem.

February 9. Tape recording. 1000 United Nations Avenue corner San Marcelino St., Ermita, Manila 1007, Philippines. 29 http://www.untvweb.com/hosts/larry-henares/ Downloaded on December 20, 2012.

30 Mapa, Placido. 2009. Interview by Yutaka Katayama, Cayetano Paderanga, Temario Rivera and Teresa S. Encarnacion Tadem. Tape recording. March 27, Metrobank Plaza, Gil Puyat Avenue, Makati City.

Kritika Kultura 20 (2013): -094

(C) Ateneo de Manila University

<http://kritikakultura.ateneo.net> 
Mapa's perspective was already evident in his doctoral dissertation topic which was inspired by his favorite economics professor Evsey Domar who created the Domar model. Mapa said that the heart and analytical part of his dissertation was the expansion of Domar's model, i.e., the investment multiplier model, except that this was for a closed economy. What Mapa did was to put in a coefficient for an open economy and this would take foreign exchange into account. ${ }^{31}$ As for Virata, Laya, Alba and Paterno, they did not see foreign investors as competitors as they did not own any local business and they even worked as consultants for multinational corporations. For Alba, his education also made him receptive to the American free enterprise system. He said that he was very much influenced by his doctoral dissertation adviser Philipp Kotler who he considers as the guru of marketing. ${ }^{32}$ As for Virata, he pointed out that his appreciation for liberalization was when he observed that after the war, the boom and bust cycles of the Philippine economy was not getting the country anywhere. He saw the solution to this in developing exports which he witnessed as an SGV consultant to Taiwan, Japan and Korea. ${ }^{33}$ The leadership's support for this development perspective was further seen when Virata brought into the PES Sicat who at that time was all set to join the Yale Economic Growth Center. Sicat, who has a PhD in Economics from Massachusetts Institute of Technology, was a strong advocate of an export-led industrialization and all-out liberalization of the economy. Sicat was a disciple of Gustav Ranis, an American economist who preached this (Lichauco 1981, 78). The entry of these technocrats into government, therefore, highlights the extent to which they have used their educational assets in a competitive game of power (Fowler 2000, 14) - that is, their being able to ease out a set of technocrats from the NEC who had a different economic vision of development. Such an economic vision for the leadership seemed to provide the panacea for the country's development at a time when "the import-substitution strategy ran aground with significantly lower growth rates in the late 1960s" (Bello 2004, 9).

\section{The Limitations of Teçhnocracy's Cultural/Social Capital During the Martial Law Regime}

The first part of this paper therefore showed how technocracy's cultural and social capital paved their way into government service given their family, educational and business networks. But it also showed was what mattered too was that they shared the same economic vision as the leadership over other technocrats who had the

31 Mapa, Placido. 2009. Interview by Yutaka Katayama, Cayetano Paderanga, Temario Rivera and Teresa S. Encarnacion Tadem. Tape recording. March 27, Metrobank Plaza, Gil Puyat Avenue, Makati City.

32 Alba, Manuel S. 2008. Interview by Yutaka Katayama and Teresa S. Encarnacion Tadem. Tape recording. December 12. Third World Studies Center, Palma Hall, University of the Philippines, Diliman, Quezon City, Philippines. 33 Virata, Cesar E.A. 20o8. Interview by Cayetano Paderanga, Temario Rivera and Teresa S. Encarnacion Tadem. Tape recording. 29 July. RCBC Plaza, Makati City, Philippines. 
similar qualifications but had a different development perspective from Marcos. This section, however, will highlight the limitations of technocracy's social capital as a power base vis-à-vis the new power relations under an authoritarian regime. As pointed out, social capital is the only capital that accumulates and grows through constant usage. Furthermore, "it is a moral resource whose supply increases rather than decreases through use and which (unlike physical capital) becomes depleted if not used" (Putnam 1993 and Civic Practices Network 1996). This section will highlight the manner in which technocracy's cultural/social capital was enhanced under and authoritarian regime as well as the manner in which it was also minimized.

To a certain extent the nature of the Virata faction's cultural capital grew during the martial law period because of the similar vision they had with the IMF/World Bank which opened the door for foreign assistance to the country, something which the leadership wanted. These technocrats would, thus, head the key economic agencies of the martial law administration with Secretary of Finance, Virata as the primus interpares of the technocrats associated with the "IMF/World Bank bloc". Virata and Mapa, in particular, dealt with economic and financial matters pertaining to trade negotiations, representations in the World Bank and the IMF and Consultative Group meetings. ${ }^{34}$ The Consultative Group consisted of the major donor countries like the United States, and Japan and multilateral institution. Its membership, embodies the hegemonic ideology advanced by corporate/finance capital which has been called "corporate liberalism" (Heffren 1985, 173-174). Thus the entry of technocracy into the martial law regime was marked by two crucial sources of social capital emanating from Marcos and the IMF/World Bank.

This growth however was only to a certain extent as Marcos ultimately stymied this technocracy faction's social capital. That is, it undermined the critical role of their social capital in pursuing "sustainable growth, good governance and social integration and harmony" (Putnam 1993, 169 and Civic Practices Network 1996, 6). This was seen in the following manner:

\section{A. GETTING RID OF THE "TECHNOPOLS"}

Marcos generally chose technocrats whose cultural and social capital, i.e., political and economic networks, were not threatening to him. None of the President's key economic officials were part of Marcos' inner circle which planned martial law. As Virata pointed out, he did not have any knowledge of the preparations for martial law. He said that it was sort of a surprise to him. ${ }^{35}$ This was the same reaction of Alba, Laya, Paterno and Mapa. Under the martial law regime, Marcos in general did not allow technocracy's social capital to go beyond the economic

34 Virata, Cesar E.A. 2007. Interview by Yutaka Katayama and Cayetano Paderanga. Tape recording. December 13. RCBC Plaza, Makati City, Philippines.

35 Virata, Cesar E.A. 2007. Interview by Yutaka Katayama and Cayetano Paderanga. Tape recording. December 13. RCBC Plaza, Makati City, Philippines.

Kritika Kultura 20 (2013): -094

(c) Ateneo de Manila University

<http://kritikakultura.ateneo.net> 
sphere. The technocrats were very much aware of this and they acknowledged that the implementation of martial rule was under the Secretary of Defense Juan Ponce Enrile and the Office of the President. ${ }^{36}$ For Virata, his major task, where Marcos gave him a free hand, was to supervise and/or coordinate with the government's financial institutions such as the Central Bank, the Budget Commission and other agencies needed for budgetary, fiscal and monetary matters. ${ }^{37}$

For technocrats who were politically threatening. Marcos got rid of them as in the case of his two Executive Secretaries Salas and Alejandro Melchor who were regarded as a "technopols", i.e., political technicians or strategists. Marcos viewed Salas as some form of political threat, particularly for the presidency. ${ }^{38}$ Salas during that time was hailed as the "rice czar" for improving rice production in the country. He was also well-connected as he came from the landowning elite and his first cousin was Roberto Benedicto, who was considered as one of Marcos' "chief cronies". As noted by Horacio "Boy" Morales, who worked closely with Salas and by Corpuz, Marcos was not the type of person who was willing to take chances even with the best and the brightest. ${ }^{39}$ When Salas saw that Marcos was lukewarm to his political ambition in running for the Senate, he left the government to become the Executive Director of the newly-established United Nations Fund for Population Activities (UNFPA) in 1969.

As for Melchor who succeeded Salas and was a U.S. Annapolis graduate, Virata described him as an action man and very efficient and was able to size up problems easily. But Virata thought that the President was not too comfortable about him because he came from the military and he was building around him a number of military officers as his assistants. ${ }^{40}$ Marcos thus abolished the Office of the Executive Secretary and Melchor was purged and sent to the Asian Development Bank (ADB) as the country's executive director. ${ }^{41}$ Salas and Melchor were two technocrats who had close relationships with members of the Virata faction.

36 Virata, Cesar E.A. 2008. Interview by Yutaka Katayama, Cayetano Paderanga and Teresa S. Encarnacion Tadem. Tape recording. June 24. RCBC Plaza, Makati City, Philippines.

37 Virata, Cesar E.A. 2008. Interview by Cayetano Paderanga and Teresa S. Encarnacion Tadem. Tape recording. June 16. RCBC Plaza, Makati City, Philippines.

38 Alba, Manuel S. 2008. Interview by Yutaka Katayama and Teresa S. Encarnacion Tadem. Tape recording. December 12. Third World Studies Center, Palma Hall, University of the Philippines, Diliman, Quezon City, Philippines; Virata, Cesar E.A. 2008. Interview by Cayetano Paderanga and Teresa S. Encarnacion Tadem. Tape recording. 16 June. RCBC Plaza, Makati City, Philippines; Corpuz, Onofre D. 2008. Interview by Yutaka Katayama, Cayetano Paderanga and Teresa S. Encarnacion Tadem. Tape recording. January 25, Corpuz Residence, U.P. Professor's Village, Tandang Sora, Quezon City, Philippines.

39 Morales, Horacio "Boy" Jr. 2009. Interview by Yutaka Katayama, Cayetano Paderanga and Teresa S. Encarnacion Tadem. Tape recording. August 14. Third World Studies Center Office, Palma Hall, University of the Philippines, Diliman, Quezon City; and Corpuz, Onofre D. 2008. Interview by Yutaka Katayama, Cayetano Paderanga and Teresa S. Encarnacion Tadem. Tape recording. January 25, Corpuz Residence, U.P. Professor's Village, Tandang Sora, Quezon City, Philippines.

40 Virata, Cesar E.A. 2007. Interview by Yutaka Katayama and Cayetano Paderanga. Tape recording. December 13. RCBC Plaza, Makati City, Philippines.

41 Virata, Cesar E.A. 2008. Interview by Yutaka Katayama, Cayetano Paderanga and Teresa S. Encarnacion Tadem. Tape recording. June 24. RCBC Plaza, Makati City, Philippines.

Kritika Kultura 20 (2013): -094

(c) Ateneo de Manila University

<http://kritikakultura.ateneo.net> 


\section{B. "FACTIONALIZATION" OF TECHNOCRACY'S SOCIAL CAPITAL"2}

Asides from limiting the Virata faction's social capital to the economic sphere, Marcos further depleted this by "factionalizing" his technocracy. A consequence of this was the emergence of non-Virata technocrats who pursued their own development projects with the support of the leadership. This weakened the economic policy-making leverage of the Virata bloc. This was seen the case of its relationship with two other technocrats, Roberto V. Ongpin and Geronimo Z. Velasco. These two technocrats also shared the economic vision of the IMF/World Bank technocracy bloc, but had their own particular "cultural capital" which gave them their own direct access to Marcos. Ongpin, who served as Marcos' Minister of Trade and Industry traces his lineage to the prominent Don Roman Ongpin clan of Manila's Chinatown in Binondo, the country's former premier commercial district in the early 1900s (Joaquin 1990, 13). Like Manila's elite, Ongpin studied in Ateneo de Manila and obtained an MBA from Harvard University. Before joining government, he was Virata's deputy in SGV where he later on went to become a partner. ${ }^{43}$ Ongpin seemed to provide Marcos with the connection he needed with the country's potent Chinese business community. He replaced Paterno as Minister of Trade in 1979, resulting into the change in policies of the Board of Investments (BOI) which was previously headed by his predecessor. ${ }^{44}$ There was the union of the Ministries of Trade and Industry into one and the downgrading of the BOI. Furthermore, Ongpin preferred big industrial developments, e.g., the Association of Southeast Asian Nation's (ASEAN) 11 industrial projects. Mapa as well as Alba observed that Ongpin had a big say on industrial policies during Marcos time. ${ }^{45}$ Virata did not approve of such a policy. ${ }^{46}$

As for Velasco, he served as Marcos' Minister of Energy from 1977 to 1986. Like Virata, Velasco obtained an MBA from the Wharton School of the University of Pennsylvania. He also served as the Chairman and President of the Philippine National Oil Company from 1973 to 1986. Velasco's background seemed to provide a particular cultural capital which were not present with the other Marcos' technocrats. That is, he was a very successful businessman and before entering government, "the country's highest-paid executive, whether Filipino or foreign" (Velasco 2006, x). At 34 years old, he was president of Republic Glass Company and president of the multinational agribusiness firm DOLE Co. (Philippines) (Velasco $2006, \mathrm{x})$. Virata also pointed out that Velasco was employed by the Standard

4.2 See Tadem, Teresa S. Encarnacion S. 2012. Virata: The trials and tribulations of a "chief technocrat". Philippine Political Science Journal 33 (1): 23-37.

43 Virata, 21 November 2007 Virata, Cesar E.A. 2007. Interview by Yutaka Katayama, Cayetano Paderanga and Teresa S. Encarnacion Tadem. Tape recording. November 21. RCBC Plaza, Makati City, Philippines.

44 Paterno, Vicente T. 2008. Interview by Yutaka Katayama, Temario Rivera and Teresa S. Encarnacion Tadem. Tape recording. August 15. 11th Floor Columbia Tower Ortigas Ave., Mandaluyong City, Philippines.

45 Mapa, Placido. 2009. Interview by Yutaka Katayama, Cayetano Paderanga and Teresa S. Encarnacion Tadem. Tape recording. April 22. Metrobank Plaza, Gil Puyat Avenue, Makati City.

46 Virata, Cesar E.A. 2008. Interview by Cayetano Paderanga, Temario Rivera and Teresa S. Encarnacion Tadem. Tape recording. 29 July. RCBC Plaza, Makati City, Philippines. 
Vacuum Oil Company (Stanvac) before the break up of Esso and Mobil. ${ }^{47}$ His networks in the energy sector seemed to provide what Marcos needed during that time as he was recruited at the height of the oil crisis in 1973 (Velasco 2006, x). The Virata faction had no control over the country's energy policies as this was generally determined by Velasco and the leadership. Marcos factionalization of technocracy, therefore, did not provide the needed social integration and harmony which allows social capital to grow (Putnam 1993, 167 and Civic Practices Network 1996).

\section{CRONY CAPITALISM AS ADVERSE SOCIAL CAPITAL}

A third way by which Marcos undermined the social capital of the Virata faction was through the nurturing of crony capitalism. Moreover, Marcos' relationship with his cronies highlighted the negative traits of social capital. That is, social capital which nurtured patronage and forms of vertical and hierarchical networks. (Putnam 1993, 173, Civic Practices Network 1996, Woolcock 1998, 271). As noted by Conrado "Jolly" Benitez, a technocrat closely identified with the First Lady Mrs. Imelda Marcos, the president in general had his own people in various economic sectors in society which were out of the hands of technocracy. ${ }^{48}$ In relation to this, the technocrats observed that Marcos' left key industries in the Philippines like the coconut and sugar industries, the country's top two major export earners during that time, in the hands of his "chief cronies", i.e., Eduardo "Danding" Cojuangco and Roberto S. Benedicto, respectively. Virata said Marcos would not discuss the coconut industry with him as well as the involvement of Cojuangco. What Virata knew was that this concept of controlling the coconut industry came from a study prepared by Ongpin when he was still with SGV..$^{49}$ Virata also felt that Enrile was also quite close to Cojuangco. For Virata, for the things that the Department of Finance (DOF) had no control, he just left it in the hands of the groups that managed them as was the case of these two industries. ${ }^{50}$ As for Benedicto, he was Marcos' classmate and fraternity brother at the UP College of Law. He was considered as one of the earliest and the most trusted cronies of Marcos (Manapat 1991, 100). Virata pointed out that sugar was out of the hands of their technocratic group and it was Benedicto who was in-charge of this..$^{51}$ In particular, sugar trading was set up to go through NASUTRA (National Sugar Trading Corporation) which

47 Virata, Cesar E.A. 2007. Interview by Yutaka Katayama, Cayetano Paderanga and Teresa S. Encarnacion Tadem. Tape recording. 19 December. RCBC Plaza, Makati City, Philippines.

48 Benitez, Jose Conrado. 2009. Interview by Yutaka Katayama and Teresa S. Encarnacion Tadem. Tape recording. August 7. Philippine Women's University, 1743 Taft Avenue, Manila, Philippines.

49 Virata, Cesar E.A. 2007. Interview by Yutaka Katayama, Cayetano Paderanga and Teresa S. Encarnacion Tadem. Tape recording. November 28. RCBC Plaza, Makati City, Philippines.

50 Virata, Cesar E.A. 2008. Interview by Yutaka Katayama, Cayetano Paderanga and Teresa S. Encarnacion Tadem. Tape recording. June 24. RCBC Plaza, Makati City, Philippines.

51 Virata, Cesar E.A. 2007. Interview by Yutaka Katayama, Cayetano Paderanga and Teresa S. Encarnacion Tadem. Tape recording. November 28. RCBC Plaza, Makati City, Philippines.

Kritika Kultura 20 (2013): -094

(C) Ateneo de Manila University

<http://kritikakultura.ateneo.net> 
was headed by Benedicto. ${ }^{22}$ The NASUTRA experience is an example how Marcos is able to create conflict among members of a wealthy sugar landowning family. As Mapa pointed out, Benedicto's monopoly of NASUTRA was very unpopular with his family and relatives ${ }^{53}$ but he (Mapa) could not do anything about it.

Depletion of socialcapital and the First Lady. The social capital of the Virata faction was further depleted as a moral resource, i.e., a resource which is able to help establish good relations within a community (Putnam 1993, 169). This was because of its difficulty of curtailing the excesses of the First Lady Mrs. Imelda Marcos. Alba pointed out that Mrs. Marcos generally left it to her trusted people like Benitez to talk to him when they needed money. But he also said that once in awhile, Marcos would tell him when they were both alone that if the First Lady has some requests, to let him (Marcos) know. Alba said that in general, he would always consult with Marcos but at the end of the day, Alba recognized the power of Mrs. Marcos in getting what she wanted being the wife of the President. ${ }^{54}$ Mapa also observed that to some extent, Virata would try to talk to Marcos about the private sector's concern of having an "equal playing field" but he would not always get what he wanted. In some instances, he said that he and Virata were in collision course with Mrs. Marcos. ${ }^{55}$

\section{Crisis and the Expansion and Contraction of Technocracy's Social Capital}

One, therefore, has a situation as pointed out by Danny Unger (1998), in his study of social capital in Thailand, of an "embedded state perspective," whereby state officials often utilize the "resources of social groups and authority structures to enhance their power (thereby) harnessing the organizational endowments of society to their own ends."Under such circumstances, therefore, the Virata faction's social capital could not grow and there was the threat of its depletion due to the absence of constant usage (Putnam 1993, 169 and Civic Practices Network 1996). It's social capital was, however, not static as it was also shaped by the dynamics between the Virata faction and the leadership as well as his cronies and Mrs. Marcos as seen in the following manner:

52 Virata, Cesar E.A. 2008. Interview by Yutaka Katayama, Cayetano Paderanga and Teresa S. Encarnacion Tadem. Tape recording. May 2. RCBC Plaza, Makati City, Philippines.

53 Mapa, Placido. 2009. Interview by Yutaka Katayama and Teresa S. Encarnacion Tadem. Tape recording. March 13, Metrobank Plaza, Gil Puyat Avenue, Makati City.

54. Alba, Manuel S. 2009. Interview by Yutaka Katayama, Cayetano Paderanga and Teresa S. Encarnacion Tadem. Tape recording. January 23. December Third World Studies Center, Palma Hall, University of the Philippines, Diliman, Quezon City, Philippines.

55 Mapa, Placido. 2009. Interview by Yutaka Katayama and Teresa S. Encarnacion Tadem. Tape recording. March 13. Metrobank Plaza, Gil Puyat Avenue, Makati City.

Kritika Kultura 20 (2013): -094

(C) Ateneo de Manila University

<http://kritikakultura.ateneo.net> 
One way by which the Virata faction built on its social capital was to assert its leverage under the martial law regime through its vital linkage with the IMF/World Bank. This was seen when Virata was confronted with proposals of relatively large projects like the petrochemicals venture proposed by Velasco and the steel mill and the blast furnace scheme of Ongpin. Virata said that he argued against these capital-intensive projects as there was no way the country could finance this given its thin reserves..$^{56}$ This was part of Ongpin's push for the country to support the ASEAN project on 11 industrial project which Marcos wanted. This project, however, did not push through because the World Bank did not adhere to this scheme and the regime could not acquire the needed foreign loans to finance this (Lichauco 1973, 107). The Virata faction would receive further support from the IMF/World Bank in the late 1970s in combating corruption and obstacles to implementing their economic policies. This was initially seen in the appointment of Virata as Prime Minister by Marcos when the president moved to convene the Interim Batasan Pambansa (National Assembly) in 1978. This was to pave the way for a French model presidential-parliamentary system and the lifting of Martial Law in 1981. Such a move surprised Virata because he knew that members of the ruling party Kilusang Bagong Uno (KBL)or New Society Movement, wanted the First Lady to be the Prime Minister. ${ }^{57}$ Moreover, the regimes' cronies led by Mrs. Marcos did not take kindly to the leadership's accommodation of technocracy's increased power even though a great part of this was nominal in nature. They believed that a technocrat-dominated Cabinet would usher in a tighter hold on their activities by the IMF and the World Bank group whose policies were not popular with them (Bowring and Sacerdoti 1983, 54). The widespread perception was that these two multilateral agencies pressured Marcos to lift martial law and declare a New Republic in 1981 headed by a Cabinet composed of World Bank technocrats led by Virata. This was one by which the IMF/World Bank felt that a "technocratic-led" Cabinet would keep in check crony monopoly of vital industries in the country which has warded off potential foreign investors in the Philippines because of the absence of competition and "free enterprise" (Bello et.al. 1982, 184).What gave further boost to technocracy's clout was the 1981 economic crisis as spawned by the oil crisis due to the Iran-Iraq war among others. This led Marcos to rely on Virata and his team to access the needed loans from the IMF/World Bank for the country. Although Virata succeeded to accomplish his mission, this was done with great difficulty as efforts to get financial support from the donor countries and agencies was further stymied with the global economic crisis. Further aggravating this was the assassination of Marcos's chief political foe ex-Senator Benigno S. Aquino on August 21, $1983 . .^{58}$

56 Virata, Cesar E.A. 2007. Interview by Yutaka Katayama, Cayetano Paderanga and Teresa S. Encarnacion Tadem. Tape recording. 19 December. RCBC Plaza, Makati City, Philippines and Virata, Cesar E.A. 2008. Interview by Cayetano Paderanga and Teresa S. Encarnacion Tadem. Tape recording. 3o September. RCBC Plaza, Makati City, Philippines.

57 Virata, Cesar E.A. 2008. Interview by Yutaka Katayama, Cayetano Paderanga and Teresa S. Encarnacion Tadem. Tape recording. May 28. RCBC Plaza, Makati City, Philippines.

58 Virata, Cesar E.A. 2008. Interview by Yutaka Katayama, Cayetano Paderanga and Teresa S. Encarnacion Tadem. Tape recording. June 24. RCBC Plaza, Makati City, Philippines. 
The possibilities of social capital expansion in times of crisis. The economic and political crisis in general however gave the opportunity for the social capital of the IMF/World Bank technocrats to grow as they attempted to clamp down on crony capitalism. Virata, for example, narrated that in 1984, there was a bank run led by Aquino's widow, Corazon, of all the state- and/or crony-owned banks such as Philippine National Bank (PNB) and the United Coconut Planters Bank (UCPB). Because of this, Marcos issued out a decree stating that the Central Bank shall be obligated to restore the funds to the Bank brought about by the rallies. This meant that if these crony-owned banks lost dollars, the government needed to restore it. Virata and Central Bank Governor Jose Fernandez successfully prevailed on Marcos to rescind this as this had no parallel or precedent in international law. Virata believed that the one who crafted the decree was the group of Cojuangcowho at that time was UCPB chairman. ${ }^{59}$

The growth of the Virata faction's social capital under such a situation also emphasizes the importance of the role of the leadership, particularly, through state intervention which "sometimes destroys developmentally promising social networks and undermines developmentally useful social norms" (Evans 1990, 4). What emerges here is technocracy's reliance on Marcos to sustain the nature of their social capital by "creating a more even balance among contending parties... as a precondition for developing forms of collaboration based on increased trust and recognition of legitimate interests" (Evans 1990, 205). This was further seen when Marcos was caught between the interests of his cronies and relatives and that of the IMF/World Bank technocrats during a KBL caucus in 1983 when the president did not lift a finger to stop the unrelenting attack against the local technocracy by members of the ruling party led by Mrs. Marcos, Benedicto, and his Minister of Labor Blas Ople who aired their frustration against the technocrats. They felt that the technocratic policies, e.g., IMF/World Bank structural adjustment programs (SAPs), stood in the way of their personal projects and interests. Taking into consideration the coming 1984 elections, Marcos also regarded this as a means "to allow the party leaders to stand up for whatever parochial interest they represented and, more importantly, to find a scapegoat for the country's economic inefficiency" (Bowring and Sacerdoti 1983, 64). The realization, however, that the regime cannot survive without IMF/WB loans and that the technocrats are indispensable (since only they can assure the country of financial assistance from international lenders), pressured Marcos to come out with a statement saying that "the KBL central committee since 1972 has always reviewed all policies and programs adopted by the Party but which are now claimed by new managers". This was his way of signaling to the party members to stop their attacks on the technocrats (Rocamora 1983, 6).

59 Virata, Cesar E.A. 2008. Interview by Cayetano Paderanga, Temario Rivera and Teresa S. Encarnacion Tadem. Tape recording. 29 July. RCBC Plaza, Makati City, Philippines.

Kritika Kultura 20 (2013): -094

(C) Ateneo de Manila University

<http://kritikakultura.ateneo.net> 
Loss of the business community's support. But the Virata faction also fell short of addressing the inequalities whereby "norms and networks that serve some groups may obstruct others, particularly if the norms are discriminatory or the networks socially segregated" (Portes and Landolt 1996, 3). This was seen during this period whereby the reforms taken by technocracy, were not enough to convince the business community in particular and the Philippine public in general that technocracy had the clout and even the political will to control crony capitalism. The business community for example, viewed the technocrats as covering up for crony corporations in the light of the 1983 Philippine economic crisis which led to the rapid downfall of more enterprises, majority of which were owned by Marcos cronies. To prevent the economy from falling apart, the technocrats stepped in to salvage some of these crony corporations (Galang, 1981). Thus, an important source of social capital which the Virata faction established during the pre-martial law period was lost.

The limitations of IMF/World Bank support. The economic clout of the Virata faction was further severed when it could not access all the needed financial assistance from the IMF/World Bank. A reason was because the hands of these two multilateral agencies were also tied during this period because its priority was to rescue first its Latin American major debtor countries of Mexico in August 1982 which defaulted followed by Brazil, Argentina, Chile, Ecuador and then the Philippines in $1983 .{ }^{60}$ Aggravating this situation for Viratawas that the U.S. was now shifting its support to Mrs. Aquino who it viewed as a pliable leader as compared to Marcos. ${ }^{61}$ This seemed to signal that politically and economically, U.S was withdrawing its support for the dictatorship and consequently, its technocrats.

What aggravated this situation was Marcos chose to seek the assistance of Ongpin to help the country get out of the economic crisis stressing a social capital where the same strong ties that help members of a group often enable it to exclude others (Portes and Landolt 1996). ${ }^{62}$ This was seen in the Virata faction's exclusion from Ongpin's network of financial assistance emanating from his Binondo ${ }^{63}$ Central Bank $(\mathrm{BCB})$, which was established through his network among the rich in the Chinese community. "The so-called BCB referred to a group of major currency traders organized in November 1983 to provide badly needed dollars to importers, traders and large corporations that acquired raw materials and services" (Inquirer Research 2012, A22). This came at the time when the country's "banks and financial institutions had scarce foreign reserves due to the crippling debt crisis that followed the assassination of Benigno Aquino Jr. (Inquirer Research 2012, A22). According

6o Virata, Cesar E.A. 2008. Interview by Cayetano Paderanga and Teresa S. Encarnacion Tadem. Tape recording. 30 September. RCBC Plaza, Makati City, Philippines.

61 Virata, Cesar E.A. 2008. Interview by Cayetano Paderanga and Teresa S. Encarnacion Tadem. Tape recording. 30 September. RCBC Plaza, Makati City, Philippines.

62 Thus "in industries with strong social ties, newcomers often find themselves unable to compete, no matter how good their skills and qualifications." (Portes and Landolt 1996).

63 Binondo refers to Chinatown in the Philippines. It is a district in Manila.

Kritika Kultura 20 (2013): -094

(C) Ateneo de Manila University

<http://kritikakultura.ateneo.net> 
to Enrile, who led the 1986 People Power military coup against Marcos, the BCB was under the Project Luntian (Green) of the National Intelligence Security Agency (Nisa). Nisa was under Armed Forces Chief of Staff General Fabian Ver who Ongpin worked closely with for this project (Yamsuan 2012, A22). This also highlighted Ongpin's close ties too with the military, something which the Virata faction did not have. Virata also said that Marcos relied on his crony Benedicto to raise the needed money, i.e., US\$125 million for the country which Laya as Central Bank governor could not do. Virata surmised that Benedicto probably called a number of people close to him and the instrument used was the Dollar Treasury Bill. ${ }^{64}$ This highlights the nature of the networks which Benedicto had which the IMF/World Bank technocrats did not possess. In the process, the Virata faction, therefore, generally lost two of its important sources of its social capital, i.e., the support of the leadership and the IMF/World Bank.

What ultimately sealed the Virata faction's demise, was that, with the exception of Paterno, who left the Marcos government in 1980 and joined the anti-dictatorship movement and Sicat who joined the World Bank, technocracy was totally alienated and even went against another valuable social capital which was undergoing a process of building and expanding new rights of participation of citizens (Putnam 1993, 96). That is, the 1986 People Power Revolution which paved the way for the downfall of the Marcos dictatorship and consequently all of his technocrats.

\section{Conclusion}

This article, therefore, has shown the pertinence of exploring the nature of cultural/social capital in the making and unmaking of technocracy as a "power elite" in Philippine society. It particularly focused on how it facilitated the emergence of the Virata faction of technocracy which was closely identified with the IMF/World Bank. What paved the way for the entry of this technocracy bloc into the martial law regime were their family and educational backgrounds which enabled them to acquire the technical expertise needed by the Philippine business community and later on by the government. They came from the different classes of Philippine society. In the case of Mapa, his family's political and sugar landowning connections helped him secure a key role in the government. But for Virata, Mapa, Laya and Sicat, this was mainly the UP connection. But what set apart the Virata faction from the other technocrats who possessed similar family and educational backgrounds and technical expertise was their shared economic vision with the leadership as well as the IMF/World Bank. This led to their retention in the martial law administration unlike the other technocrats. This also enabled the growth of their social capital mainly as facilitator of international loans from donor countries and multilateral institutions.

64 Virata, Cesar E.A. 2008. Interview by Yutaka Katayama, Cayetano Paderanga and Teresa S. Encarnacion Tadem. Tape recording. June 24. RCBC Plaza, Makati City, Philippines.

Kritika Kultura 20 (2013): -094

(C) Ateneo de Manila University

<http://kritikakultura.ateneo.net> 
The martial law period, however, also showed how Marcos stymied the Virata faction's social capital by doing the following: 1) he limited its social capital to the economic sphere and the Virata faction had nothing to do with politics; Marcos even got rid of "technopols" who he considered were "threatening"; 2) he factionalized technocracy thus it did not move as one power bloc; 3) he encouraged a negative form of social capital through crony capitalism, as was particularly seen in his nurturing of two chief cronies, i.e., Cojuangco in the coconut industry and Benedicto in the sugar industry; and lastly 4) he did not curtail the excesses of his wife Mrs. Marcos. All of these stymiedthe Virata faction's social capital to pursue its economic policies.

The political and economic crisis, however, also revealed the possibilities of how the Virata faction's social capital could still grow as seen with the IMF/ World Bank pressure on the leadership to form a technocratic government headed by no less than Virata as Prime Minister. This was one way it believed that it could restrain patronage politics and corruption in the martial law regime. The economic and political crisis of the early 1980 os also gave some leverage for the Virata faction to institute reforms in exchange for financial assistance from these multilateral lending agencies. This was, however, short-lived as the Virata faction could not access all the financial assistance the country needed. A major reason was that IMF/World Bank gave priority in bailing out its bigger Latin American debtor countries. Furthermore, the emergence of Mrs. Aquino as an alternative to Marcos, gave impetus for the U.S. to withdraw its support for the dictatorship, and consequentlys its technocrats. Marcos thus shifted his dependence on the Virata faction to his other technocrat, Ongpin and chief crony, Benedicto to bring in the needed dollar reserves. This only further depleted whatever social capital was left of an already emasculated Virata technocracy bloc. 


\section{Works Cited:}

Bello, Walden, David Kinsley and Elaine Elinson. 1982. Development Debacle: The World Bank in the Philippines. California: Institute for Food and Development Policy, 1982), p. 184.

Bello, Walden. 2004. The Anti-Developmentalist State: The Political Economy of Permanent Crisis in the Philippines. Quezon City: Department of Sociology, College of Social Sciences and Philosophy, and Focus on the Global South.

Bowring, Philip and Guy Sacerdoti. 1983. "Time for a Real Debate”. Far Eastern Economic Review, 9 June.

Castro, Amado. 1974. "Import-Substitution in the Philippines, 1954-1961: A Historical Interpretation." Discussion Paper 74-21, Institute of Economic Development and Research, School of Economics, University of the Philippines in Rivera, Temario C. 1994. Landlords and capitalists: Class, family, and state in Philippine manufacturing. Quezon City: Center for Integrative and Development Studies and the University of the Philippines Press.

Civic Practices Network, “Social Capital”, (CPN Internet Webpage) 1996.

Croteau, David. 1995. Politics and the Class Divide: Working People and the MiddleClass Left. Philadelphia: Temple University Press.

de Dios, Emmanuel S. and Hutchcroft, Paul D. 2003. "Political Economy," in Balisacan, Arsenio and Hal Hill, The Philippine Economy: Development, Policies, and Challenges. Quezon City:Ateneo de Manila University Press.

Evans, Peter. 1990. Ed. State-Society Synergy: Government and Social Capital in Development. Berkeley: University of California Press.

Fischer, Frank. 1990. Technocracy and the Politics of Expertise. London: SAGE Publications.

Fowler, Bridget. 200o. Introduction to Reading Bourdieu on Society and Culture. Oxford: Blackwell Publisher.

Hawes, Gary. 1987. The Philippine State and the Marcos Regime: The Politics of Export. Ithaca and London: Cornell University Press.

Heffren, M. 1985. "Ideology and Hegemonic Projects: The Alliance Between Corporate Capital and the New Middle Classes in Early Twentieth-Century United States." In Johnson, Dale L. ed. Class and Social Development: A New Theory of the MiddleClass. London: Sage Publications. 
Hutchcroft, Paul D. 1998. Booty Capitalism: The Politics of Banking in the Philippines. Quezon City: Ateneo de Manila University Press.

Inquirer Research. 2011. "In the Know". Philippine Daily Inquirer. December 12, A22.

Joaquin, Nick. 1990. Jaime Ongpin the Enigma: A Profile of a Filipino Manager. Makati, MetroManila: The Jaime V. Ongpin Institute of Business and Government.

Lichauco, Alejandro. 1981. "Notes on the Political and Economic Situation: The Struggle against Underdevelopment in the Philippines". February 16, unpublished.

Manapat, Ricardo. 1991. Some Are Smarter Than Others, The History of Marcos Crony Capitalism. New York: Aletheia Publications.

McCoy, Alfred W. 1994. Editor. "An Anarchy of Families: The Historiography of State and Family in the Philippines," in An Anarchy of Families: State and Family in the Philippines, Quezon City: Ateneo de Manila University Press.

Meynaud, Jean. 1980. Technocracy. New York: Evans in Fischer, Frank. 1990. Technocracy and the Politics of Expertise. London: SAGE Publications.

Portes, Alejandro and Patricia Landolt. 1996. "The Downside of Social Capital”. The American Prospect no. 26 May-June.

Poupeau, Frank. 200o."Section II:Reasons for Domination, Bourdieu versus Habermas," in BridgetFowler, Reading Bourdieu on Society and Culture. Oxford: Blackwell Publisher.

Putnam, Robert D. (with Robert Leonardi and Raffaella Y. Nanetti). 1993. Making Democracy Work: Civic Traditions in Modern Italy. Princeton: New Jersey.

Raquiza, Antoinette R. 2012. State Structure, Policy Formation, and Economic Development in Southeast Asia: The political economy of Thailand and the Philippines. London and New York: Routledge Taylor and Francis Group.

Rivera, Temario C. 1994. Landlords and capitalists: Class, family, and state in Philippine manufacturing. Quezon City: Center for Integrative and Development Studies and the University of the Philippines Press.

Robison, Richard and David S.G. Goodman. 1996. "The New Rich in Asia: Economic Development, Social Status and Political Consciousness," in Robison, Richard and David S.G. Goodman. Eds. The New Rich in Asia: Mobile Phones, McDonalds and Middle-Class Revolution. London and New York:Routledge. 
Rocamora, Nancy. 1983. "Cesar Virata-Technocrats under Fire". Ang Katipunan, June, p. 6.

Sacerdoti, Guy. 1983. "Marcos Murmurs Cut!" Far Eastern Economic Review, 20 January.

Carmen Sirianni and Lewis Friedland, "Social Capital and Civic Innovation: Learning and Capacity Building from the 1960 s to the 199os", paper presented at the Social Capital session of the American Sociological Association Annual Meetings, Aug. 20, 1995, Washington, D.C.

Sulfikar Amir. 2007. Symbolic Power in a Technocratic Regime: The Reign of B.J. Habibie inNew Order Indonesia. Journal of Social Issues in Southeast Asia, 22, pp. 83-106.

Swartz, D. 2007. Culture and Power: The Sociology of Pierre Bourdieu (Chicago: Chicago University Press, 2007), cited in Sulfikar Amir, "Symbolic Power in a Technocratic Regime: The Reign of B.J. Habibie in New Order Indonesia," Sojourn: Journal of Social Issues in Southeast Asia, 22 (1): 75-76.

Tadem, Teresa S. Encarnacion. 2012. "Virata: the trials and tribulations of a "chief technocrat". Philippine Political Science Journal. Volume 33 Issue o1, June, pp. 23-37.

Wacquant, Loic. 2005. Pierre Bourdieu and Democratic Polity: The Mystery of Ministry Cambridge, UK: Polity Press.

Woolcock,Michael. 1998. "Social Capital and Economic Development: towards a theoretical synthesis and policy framework," Theory and Society (No. 27: 151-208) 1998.

Yamsuan, Cathy. 2011. "Open records of Marcos' spy agency, Enrile urges". Philippine Daily Inquirer. December 12, A22.

Velasco, Geronimo. 2006. Trailblazing: The Quest for Energy Self-Reliance”. Manila: Anvil. 